SULFUR ISOTOPIC COMPOSITION AND WATER CHEMISTRY IN WATER FROM THE HIGH PLAINS AQUIFER, OKLAHOMA PANHANDLE AND SOUTHWESTERN KANSAS

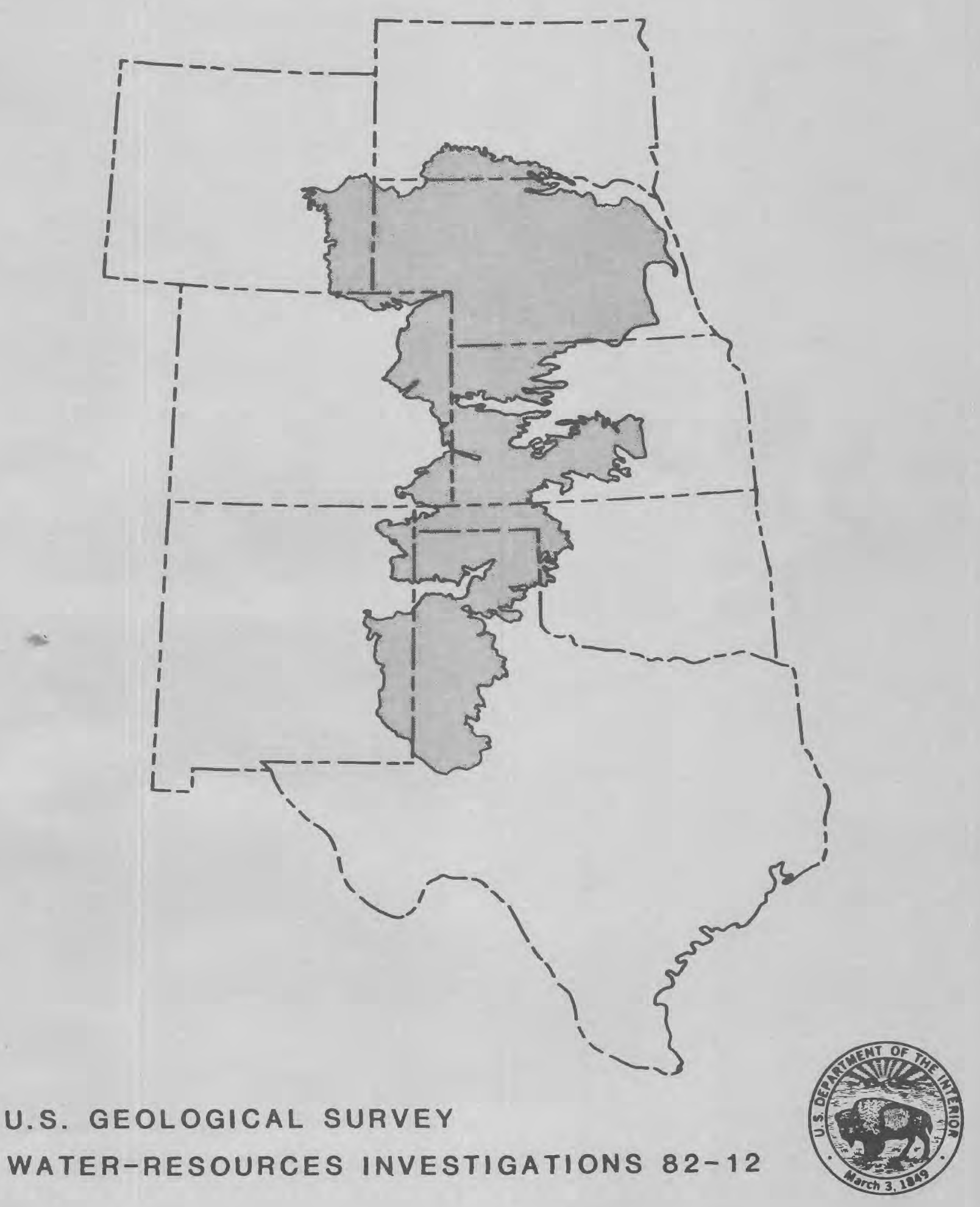




\begin{tabular}{|c|c|c|c|}
\hline REPORT I & $\begin{array}{l}\text { DOCUMENTATION } \\
\text { PAGE }\end{array}$ & $\begin{array}{l}\text { 1. REPORT NO. WRI }-82-12 \\
\end{array}$ & 3. Recipient's Accession No. \\
\hline \multirow{2}{*}{\multicolumn{3}{|c|}{$\begin{array}{l}\text { 4. Title and Subtitle } \\
\text { Sulfur isotopic composition and water chemistry in water from } \\
\text { the High Plains aquifer, Oklahoma Panhandle and southwestern } \\
\text { Kansas }\end{array}$}} & $\begin{array}{l}\text { 5. Report Date } \\
\text { March } 1982\end{array}$ \\
\hline & & & 6. \\
\hline \multicolumn{3}{|c|}{ 7. Author(s) Noel C. Krothe, and Joseph W. Oliver } & $\begin{array}{l}\text { 8. Performing Organization Rept. No. } \\
\text { USGS/WRI } 82-12\end{array}$ \\
\hline \multirow{2}{*}{\multicolumn{3}{|c|}{$\begin{array}{l}\text { 9. Performing Organization Name and Address } \\
\text { U.S. Geological Survey, Water Resources Division } \\
\text { Box 25046, Mail Stop 406 } \\
\text { Denver Federal Center } \\
\text { Denver, Colorado } 80225\end{array}$}} & 10. Project/Tesk/Work Unit No. \\
\hline & & & $\begin{array}{l}\text { 11. Contract(C) or Grant(G) No. } \\
\text { (C) } \\
\text { (G) }\end{array}$ \\
\hline \multirow{2}{*}{\multicolumn{3}{|c|}{$\begin{array}{l}\text { 12. Sponsoring Organization Name and Addrass } \\
\text { U.S. Geological Survey, Water Resources Division } \\
\text { Box } 25046 \text {, Mail Stop } 406 \\
\text { Denver Federal Center } \\
\text { Denver, Colorado } 80225\end{array}$}} & $\begin{array}{l}\text { 13. Type of Report \& Perlod Covered } \\
\text { Final }\end{array}$ \\
\hline & & & 14. \\
\hline
\end{tabular}

15. Supplementary Notes

16. Abstract (Limit: 200 words)

Regional ground-water flow in the ogallala Formation is from west to east across Kansas and Oklahoma; concentration of dissolved solids increases in the direction of flow. This increase may be influenced by residence time, but underlying bedrock appears to control ground-water chemistry. The Ogallala Formation is underlain by Mesozoic rocks in the west and Permian rocks in the east. Mean concentration of dissolved solids in ground water from the Mesozoic rocks is 552 milligrams per liter, and from the Permian rocks is 4,720 milligrams per liter. Mean concentration of dissolved solids for water in the Ogallala Formation is 396 milligrams per liter where it overlies Mesozoic rocks and $569 \mathrm{milligrams}$ per liter where it overlies Permian rocks. $\delta^{34} \mathrm{~S}\left(\mathrm{SO}_{4}\right)$ (sulfate) values range from a high of +6.9 parts per thousand to a low of -25.1 parts per thousand. Sulfate increases from about 20 milligrams per liter to more than 350 milligrams per liter from west to east. Increasing concentration of dissolved solids, lighter $\delta^{34} \mathrm{~S}$ values and increasing $\mathrm{SO}_{4}=$ (sulfate) in the eastern part of the study area incidate that ground water or $\mathrm{H}_{2} \mathrm{~S}$ (hydrogen sulfide) from Permian rocks may be moving upward into the Ogallala Formation.

17. Document Analysis a. Descriptors

*Groundwater, *Water Chemistry, Groundwater Movement

b. Identifiers/Open-Ended Terms

High Plains, Ogallala Formation, Kansas, Oklahoma, Sulfur Isotopes

c. COSATI Field/Group

18. Avallability Statemen:

No restriction on distribution

\begin{tabular}{|l|} 
19. Security Class (This Report) \\
UNCLASSIFI BD \\
\hline $\begin{array}{l}\text { 20. Security Class (This Page) } \\
\text { UNCLASSIFIED }\end{array}$ \\
\hline
\end{tabular}

21. No. of Pages 32 22. Price DPTIONAL FORM $272(4-77)$ (Formerly NTIS-35) Department of Commerce 


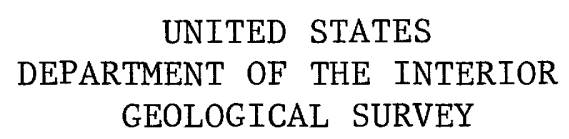

SULFUR ISOTOPIC COMPOSITION AND WATER CHEMISTRY IN WATER FROM THE HIGH PLAINS AQUIFER, OKLAHOMA PANHANDLE AND SOUTHWESTERN KANSAS

By Noel C. Krothe and Joseph W. Oliver

U.S. GEOLOGICAL SURVEY

Water-Resources Investigations $82-12$

Denver, Colorado 
UNITED STATES DEPARTMENT OF THE INTERIOR

JAMES G. WATT, Secretary

GEOLOGICAL SURVEY

Dallas L. Peck, Director

For more information write to:

Regional Hydrologist

Water Resources Division, Central Region

U.S. Geological Survey

Box 25046, Mail Stop 406

Denver Federal Center

Lakewood, Colorado 80225 
Abstract--_-

Introduction-

Description of High Plains aquifer- 5

Ground-water chemistry variations- 6

Sulfur isotopes in ground water- 10

Conclusions-_- 12

References cited--_--_-_-_-_- 28

\section{ILLUSTRATIONS}

Figure 1. Index map showing the High Plains aquifer and study area---- 3

2. Map showing sampling-site locations and numbers--_-_-_-_ 4

3. Map showing bedrock underlying the Ogallala Formation and dissolved-solids concentration in 67 water samples collected from the Ogallala Formation, 1979-80----_---- 9

4. Map showing bedrock underlying the Ogallala Formation and the distribution of $\delta^{34} \mathrm{~S}\left(\mathrm{SO}_{4}=\right.$ ) in water samples from the Ogallala Formation-_-

\section{TABLES}

Table 1. Statistical summary of selected chemical parameters from 93 water samples from the Oklahoma Panhandle and

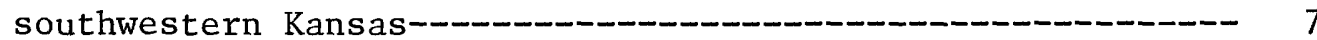

2. Chemical data from water samples collected from the High Plains aquifer in southwestern Kansas, 1979-80--_-_-_--- 14

3. Chemical data from water samples collected from the High Plains aquifer in the Oklahoma Panhandle, 1979-80------- 19

\section{CONVERSION TABLE}

Multiply inch-pound units

square mile

gallon per minute
By

2.590

0.06309
To obtain metric unit square kilometer liter per second 


\title{
SULFUR ISOTOPIC COMPOSITION AND WATER CHEMISTRY IN \\ WATER FROM THE HIGH PLAINS AQUIFER, OKLAHOMA PANHANDLE \\ AND SOUTHWESTERN KANSAS
}

By

Noel C. Krothe and Joseph W. Oliver

\begin{abstract}
The Ogallala Formation comprises the High Plains aquifer in Oklahoma and southwestern Kansas. Regional ground-water flow is from west to east in the Ogallala Formation, and the concentration of dissolved solids in ground water increases in the direction of flow. This increase may be influenced by residence time, but underlying bedrock appears to control ground-water chemistry. The Ogallala Formation is underlain by Mesozoic rocks in the west and Permian rocks in the east. Mean concentration of dissolved solids in ground water from the Mesozoic rocks is 552 milligrams per liter and Permian rocks is 4,720 milligrams per liter. Mean concentration of dissolved solids for water in the Ogallala Formation is 396 milligrams per liter where it overlies Mesozoic rocks and 569 milligrams per liter where it overlies Permian rocks. $\delta^{34} \mathrm{~S}\left(\mathrm{SO}_{4}^{\bar{E}}\right)$ (sulfate) values range from a high of +6.9 parts per thousand to a low of -25.1 parts per thousand. Sulfate increases from about 20 milligrams per 1iter to more than 350 milligrams per liter from west to east. Increasing concentration of dissolved solids, lighter $\delta^{34} \mathrm{~S}$ values, and increasing $\mathrm{SO}_{4}$ (sulfate) concentration in the east implies that ground water or $\mathrm{H}_{2} \mathrm{~S}$ (hydrogen sulfide) from Permian rocks may be moving upward into the Ogallala Formation.
\end{abstract}




\section{INTRODUCTION}

Sulfur-bearing chemical species most commonly found dissolved in lowtemperature natural waters are $\mathrm{SO}_{4}^{=}$(sulfate), $\mathrm{HS}^{-}$(ionic hydrogen sulfide), and $\mathrm{H}_{2} \mathrm{~S}$ (molecular hydrogen sulfide); the dominant species depends on the oxidation potential and $\mathrm{pH}$ of the system. The common sources of these species in ground-water systems are solution of evaporite minerals, mixing with encroaching ocean waters, decomposition of organic matter, solution and oxidation of sulfide minerals, migration of $\mathrm{H}_{2} \mathrm{~S}$, and recharge by sulfatebearing precipitation (Rightmire and others, 1974).

Sulfur has four stable isotopes, the most common of which are ${ }^{32} \mathrm{~S}$, with a relative abundance of 94.9 percent, and ${ }^{34} \mathrm{~S}$, with a relative abundance of 4.3 percent. The other two isotopes, ${ }^{33} \mathrm{~S}$ and ${ }^{35} \mathrm{~S}$, constitute the remaining 0.8 percent. The isotopic composition of sulfur may be characterized by the ratio of ${ }^{34} \mathrm{~S} /{ }^{32} \mathrm{~S}$; in this report, sulfur-isotope variations are reported in standard $\delta$ notation as:

where $R={ }^{34} \mathrm{~S} /{ }^{32} \mathrm{~S}$.

$$
\delta^{34} \mathrm{~S}=\left[\frac{\mathrm{R} \text { sample }}{\mathrm{R} \text { standard }}-1\right] \times 10^{3},
$$

Analyses in this study are reported in parts per thousand (0/00) relative to the Canyon Diablo meteorite standard. A sample that is $+100 / 00$ contains 10 parts per thousand or 1 percent more than the standard. A sample that is -10 0/00 contains 10 parts per thousand or 1 percent less than the standard. Sulfate analyses in this study were prepared by techniques used by Thode and others (1961), in which the isotopic composition of sulfur in $\mathrm{SO}_{2}$ is determined by mass spectrometry.

The purpose of this report is to identify the sources of sulfate in ground water using water chemistry and sulfur-isotope data. The possible leakage of water or $\mathrm{H}_{2} \mathrm{~S}$ upward from Permian age rocks into the Tertiary Ogallala Formation in the Oklahoma Panhandle and southwestern Kansas is discussed. The study area consists of Cimmarron, Texas, and Beaver Counties in Oklahoma; and Morton, Stevens, Seward, and Meade Counties in Kansas (figs. 1 and 2). 


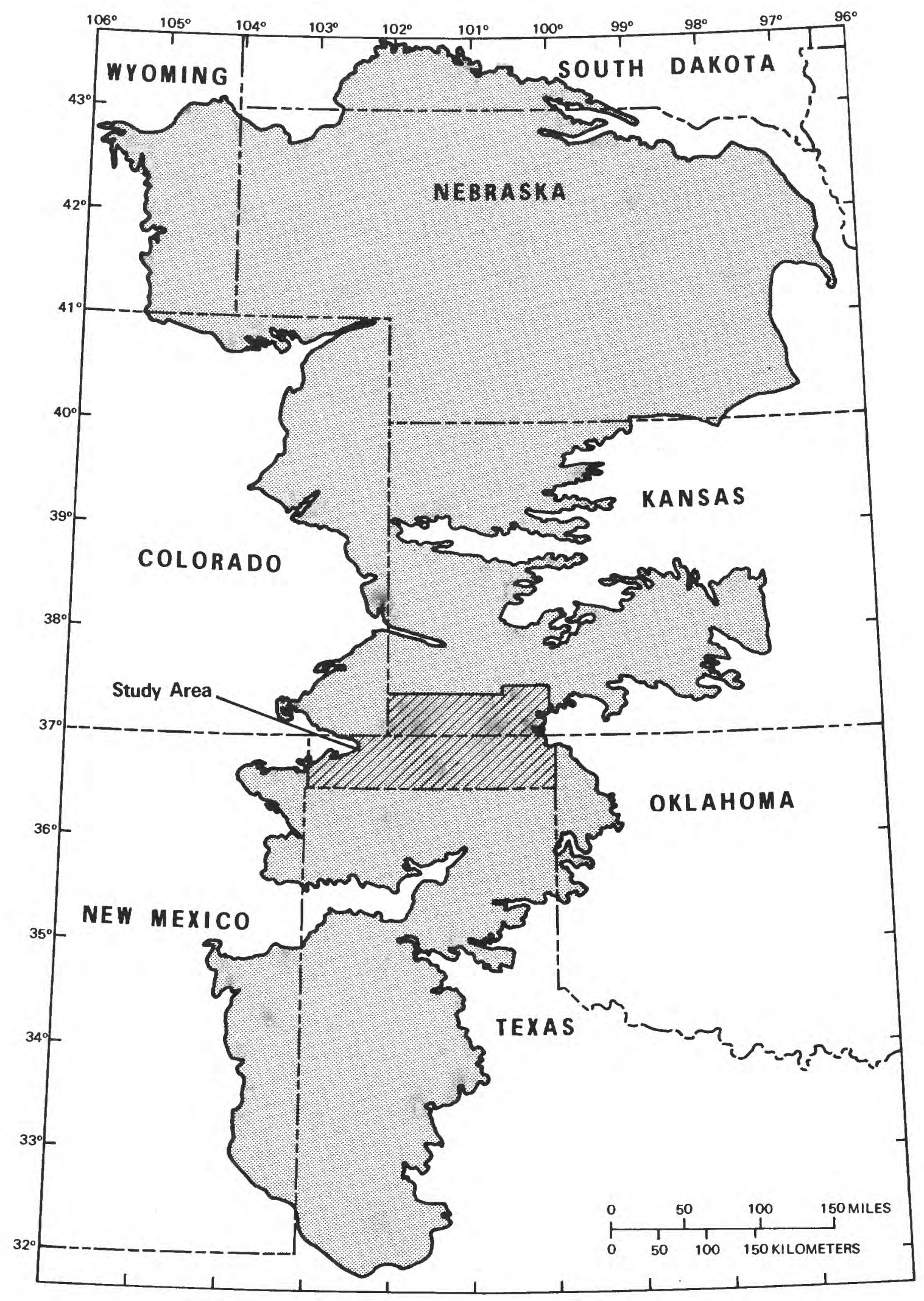

Figure 1.--Location of the High Plains aquifer (shaded) and study area. 


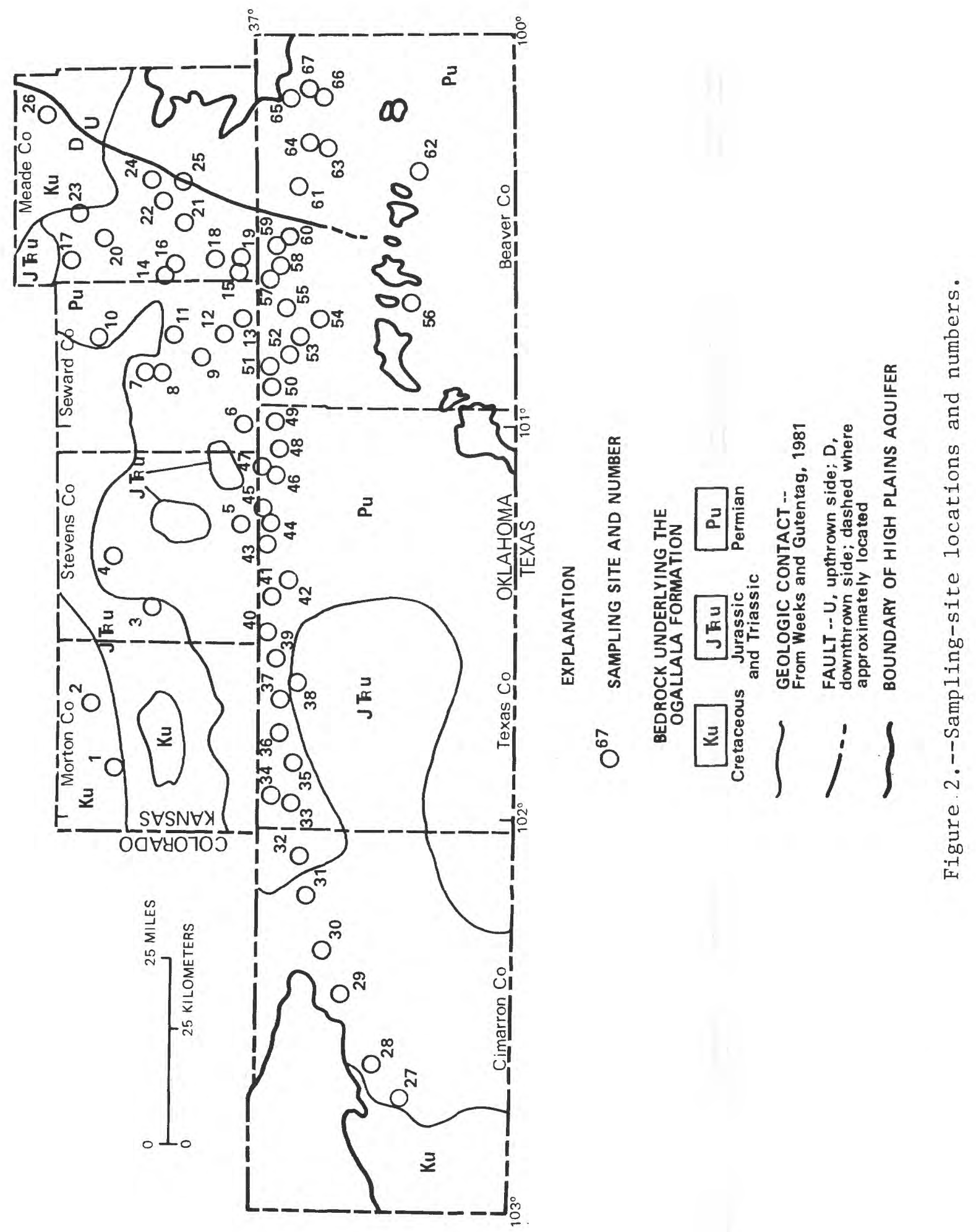


The High Plains region is a remnant of a vast plain formed by sediments deposited by streams flowing eastward from the Rocky Mountains. Subsequently, erosion isolated the plains from the mountains and formed escarpments that typically mark the boundary of the High Plains. Wind-blown sand and silt, derived from the beds of rivers that eroded the plains, were deposited over large areas of the High Plains. The fluvial (stream-deposited) and eolian (wind-blown) sediments that form the High Plains comprise the High Plains aquifer, which is a water-table system.

The geology of the High Plains aquifer was described by Gutentag and Weeks (1980) and Weeks and Gutentag (1981). The aquifer consists mainly of Tertiary and Quaternary material and covers about 174,000 square miles in eight States--Colorado, Kansas, Nebraska, New Mexico, Oklahoma, South Dakota, Texas, and Wyoming (fig. 1).

The Ogallala Formation is the major water-bearing unit of the High Plains aquifer. The Ogallala underlies 156,000 square miles and consists of semiconsolidated clay, sand, silt, and gravel. Recharge of ground water to the Ogallala is primarily from precipitation, but small amounts may be due to return flow from irrigation, infiltration from lakes, streams, and rivers, and subsurface inflow from underlying rocks. Wells in this aquifer commonly yield 500 to 1,000 gallons per minute and may yield as much as 2,500 gallons per minute.

The consolidated rocks underlying the study area range in age from Cretaceous in the western part of the study area to Permian in the eastern part (fig. 2). The Cretaceous, Jurassic, and Triassic rocks in the western part of the study area consist predominantly of thin to thick bedded sandstone with interbedded shale, conglomerate, siltstone, and lesser amounts of limestone and dolomite. The Permian rocks in the eastern part of the study area consist of thick sequences of interbedded red shale, siltstone, sandstone, gypsum, anhydrite, dolomite, bedded salt, and local limestone beds. 
Previous reports show that regional ground-water flow is from west to east across the Oklahoma Panhandle (Hart and others, 1976) and southwestern Kansas (Hathaway and others, 1978). These reports also show that specific conductance and the concentration of dissolved solids in ground water generally increase in the direction of flow.

\section{GROUND-WATER CHEMISTRY VARIATIONS}

Initially, 93 chemical analyses of ground water from the study area were reviewed to confirm the trends shown by previous investigators. The data were obtained from WATSTORE (Water Data Storage and Retrieval System) files of the U.S. Geological Survey. The data for selected chemical parameters are summarized in table 1 . The data confirm that higher concentrations of dissolved constituents in water samples from the Ogallala Formation generally occur in the eastern part of the study area where the underlying rocks are of Permian age. The mean concentration of dissolved solids in 11 water samples from Mesozoic rocks is $552 \mathrm{mg} / \mathrm{L}$ (milligrams per 1iter), and the mean concentration of dissolved solids in 25 water samples from the overlying Ogallala Formation is $396 \mathrm{mg} / \mathrm{L}$. The mean concentration of dissolved solids in 6 water samples from Permian rocks is $4,720 \mathrm{mg} / \mathrm{L}$, and the mean concentration in 51 water samples from the overlying ogallala Formation is $569 \mathrm{mg} / \mathrm{L}$. The data in table 1 indicate similar variations in the concentrations of sodium-plus-potassium, chloride, and sulfate; however, the range and standard deviation of the concentration of sulfate in water samples from the Ogallala Formation is larger where the Ogallala overlies Mesozoic rocks than where it overlies Permian rocks (table 1 ).

Because of the correlation between water-chemistry variations and bedrock changes, 67 additional water samples from the High Plains aquifer were collected to determine whether sulfur isotopes could be used to identify the cause of the variation in chemistry. Ground-water samples were collected from 40 irrigation wells, 6 stock wells, 20 domestic well, and 1 industrial well during 1979 and 1980. The locations of these sampling sites are shown 


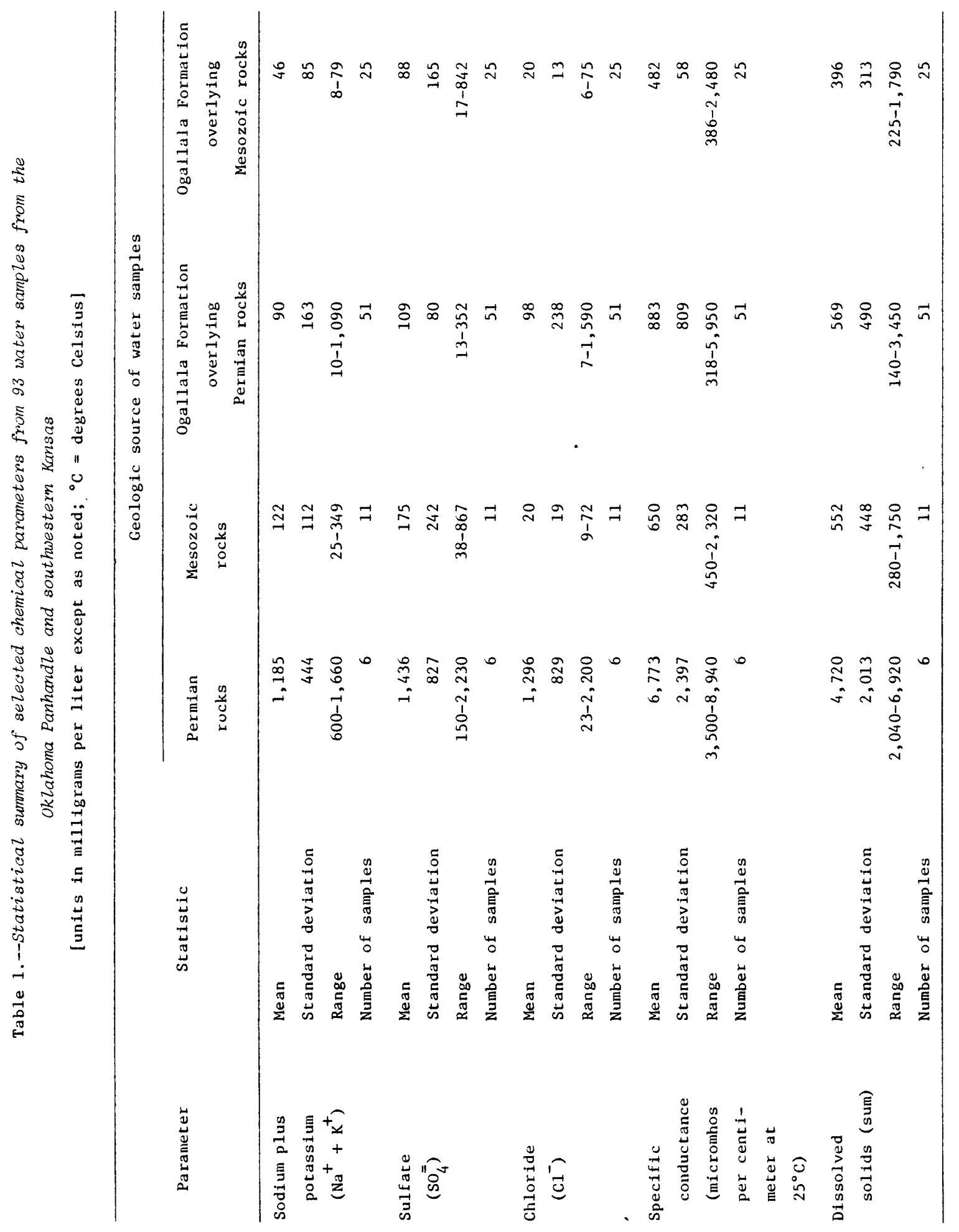


in figure 2. All wells had been in operation prior to sampling. Samples were collected at the wellhead whenever possible to minimize the possibility of contamination. Temperature, specific conductance, dissolved oxygen, bicarbonate, and $\mathrm{pH}$ were measured in the field. Samples prepared by standard techniques were analyzed for trace elements, major ions, oxygen isotopes, and sulfur isotopes at the U.S. Geological Survey's national water quality laboratory.

Results of the chemical analysis of the 67 water samples are presented in tables 2 and 3 (at the back of this report), and the dissolved-solids concentrations are shown in figure 3. The data (fig. 3) indicate that the concentration of dissolved solids increases from west to east in the direction of ground-water flow. West of $102^{\circ} \mathrm{W}$ longitude, the mean dissolved-solids concentration is $304 \mathrm{mg} / \mathrm{L}$, based on 6 water samples. Between $101^{\circ} \mathrm{W}$ and $102^{\circ} \mathrm{W}$ longitude, the mean dissolved-solids concentration is $397 \mathrm{mg} / \mathrm{L}$, based on 22 water samples. East of $101^{\circ} \mathrm{W}$ longitude, the mean dissolved-solids concentration is $472 \mathrm{mg} / \mathrm{L}$, based on 39 water samples (fig. 3 and tables 2 and 3 ).

This increase in the concentration of dissolved solids primarily is due to increasing concentrations of sodium, chloride, and sulfate (tables 2 and 3 ). Based on the data in tables 2 and 3, the mean sodium concentration increases from $21 \mathrm{mg} / \mathrm{L}$ west of $102^{\circ} \mathrm{W}$ longitude to $64 \mathrm{mg} / \mathrm{L}$ east of $101^{\circ} \mathrm{W}$ longitude. Similarly, the mean chloride concentration increases from $23 \mathrm{mg} / \mathrm{L}$ to $75 \mathrm{mg} / \mathrm{L}$ and the mean sulfate concentration increases from $42 \mathrm{mg} / \mathrm{L}$ to $85 \mathrm{mg} / \mathrm{L}$.

Although the highest concentrations of dissolved solids occur in the eastern part of the study area where the bedrock underlying the aquifer is of Permian age, not all water samples contain high concentrations. As shown by figure 3 and tables 2 and 3 , the concentrations of dissolved constituents in about one-half of the samples east of $101^{\circ} \mathrm{W}$ longitude do not contain significantly higher concentrations than those samples west of $102^{\circ} \mathrm{W}$ 1ongitude. If the water chemistry is affected by water moving upward from the Permian bedrock into the Ogallala Formation, then ground-water flow along 


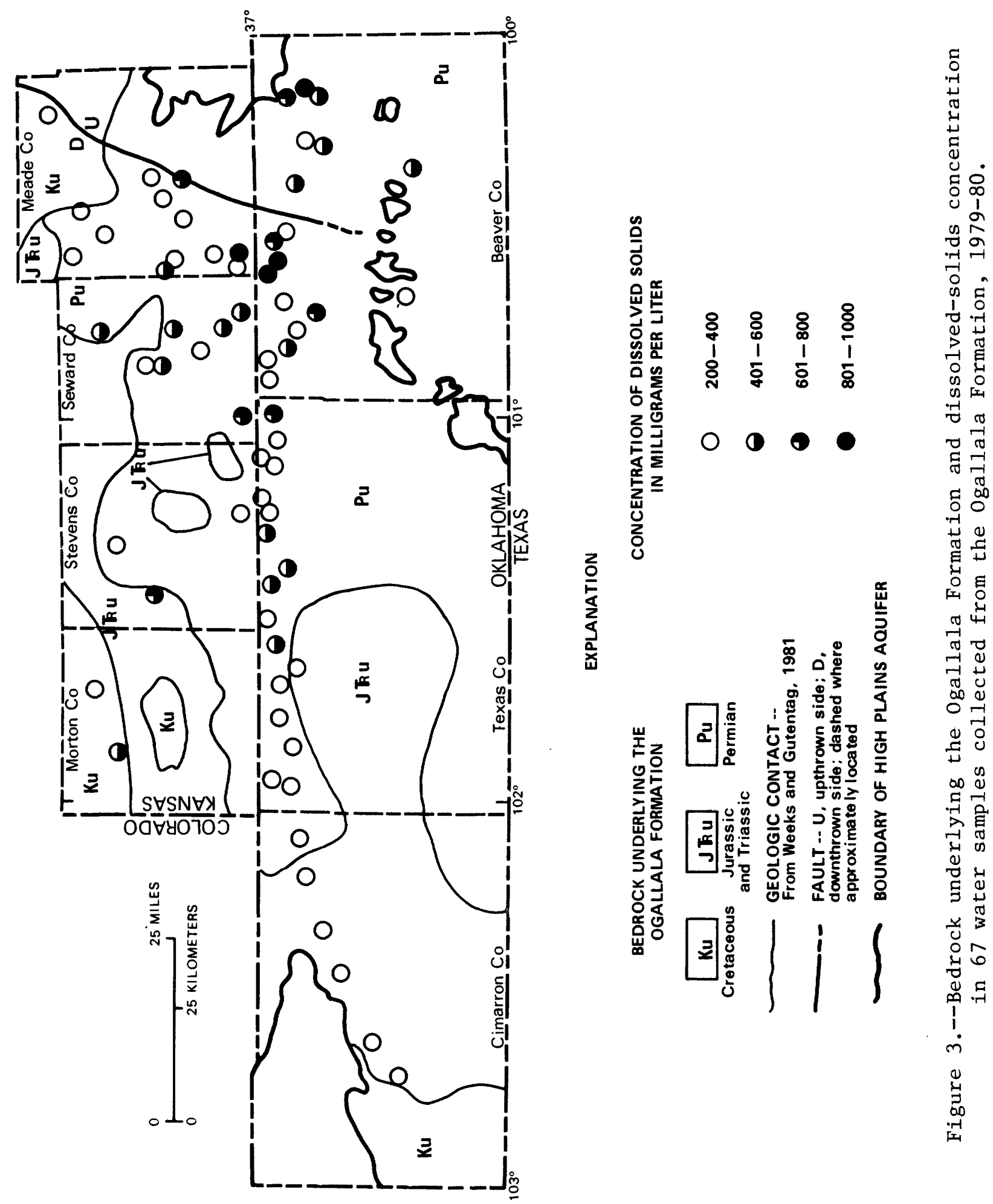


joints or fractures associated with faulting (fig. 3) in the Permian rock, leakage from improperly plugged bedrock wells, and (or) vertical chemical gradients in the Ogallala Formation could account for locally high concentrations of dissolved solids.

SULFUR ISOTOPES IN GROUND WATER

The sulfur-isotope composition of ground water in the study area (tables 2 and 3) was analyzed for possible anomalies that would substantiate upward movement of water into the Ogallala Formation from the Permian bedrock; results of this analysis are summarized in figure 4. Ground water in the western part of the study area contains mostly positive $\delta^{34} \mathrm{~S}\left(\mathrm{SO}_{4}^{=}\right)$with a maximum value of $+3.60 / 00$. There are a few negative values in this area, but none is less than $-2.40 / 00$. In the eastern part of the study area, most of the $\delta^{34} \mathrm{~S}\left(\mathrm{SO}_{4}\right)$ values are negative and range from +6.9 to $-25.10 / 00$ (fig. 3). The isotopic composition of the water in the eastern part of the study area is atypical for ground-water sulfates.

The occurrence of $\delta^{34} \mathrm{~S}\left(\mathrm{SO}_{4}^{\bar{C}}\right)$ values as low as those observed in the shaded area of figure 4 can be explained by the oxidation of sulfide minerals or oxidation of $\mathrm{HS}^{-}$or $\mathrm{H}_{2} \mathrm{~S}$. The depositional history of the Ogallala Formation and the present oxidizing condition of the ground water generally preclude the presence of sedimentary sulfides or generation of $\mathrm{HS}^{-}$or $\mathrm{H}_{2} \mathrm{~S}$ within the formation. Therefore, transport of isotopically light sulfur species into the Oga1lala Formation is suspected.

The area of negative $\delta^{34} \mathrm{~S}\left(\mathrm{SO}_{4}^{\overline{2}}\right)$ values in the Ogallala shown in figure 4 could be explained by the release of isotopically light sedimentary sulfides into solution as dissolved sulfates in ground water in the Permian rocks. If water in Permian rocks is migrating upward, the isotopically light sulfates would be found in water samples from the Ogallala Formation. This assumes that water in Permian rocks has negative delta values for sulfur. Water samples from Permian rocks were collected from four piezometers in Morton and Stevens Counties, Kansas. The $\delta^{34} \mathrm{~S}\left(\mathrm{SO}_{4}^{\bar{a}}\right)$ values from these samples were 


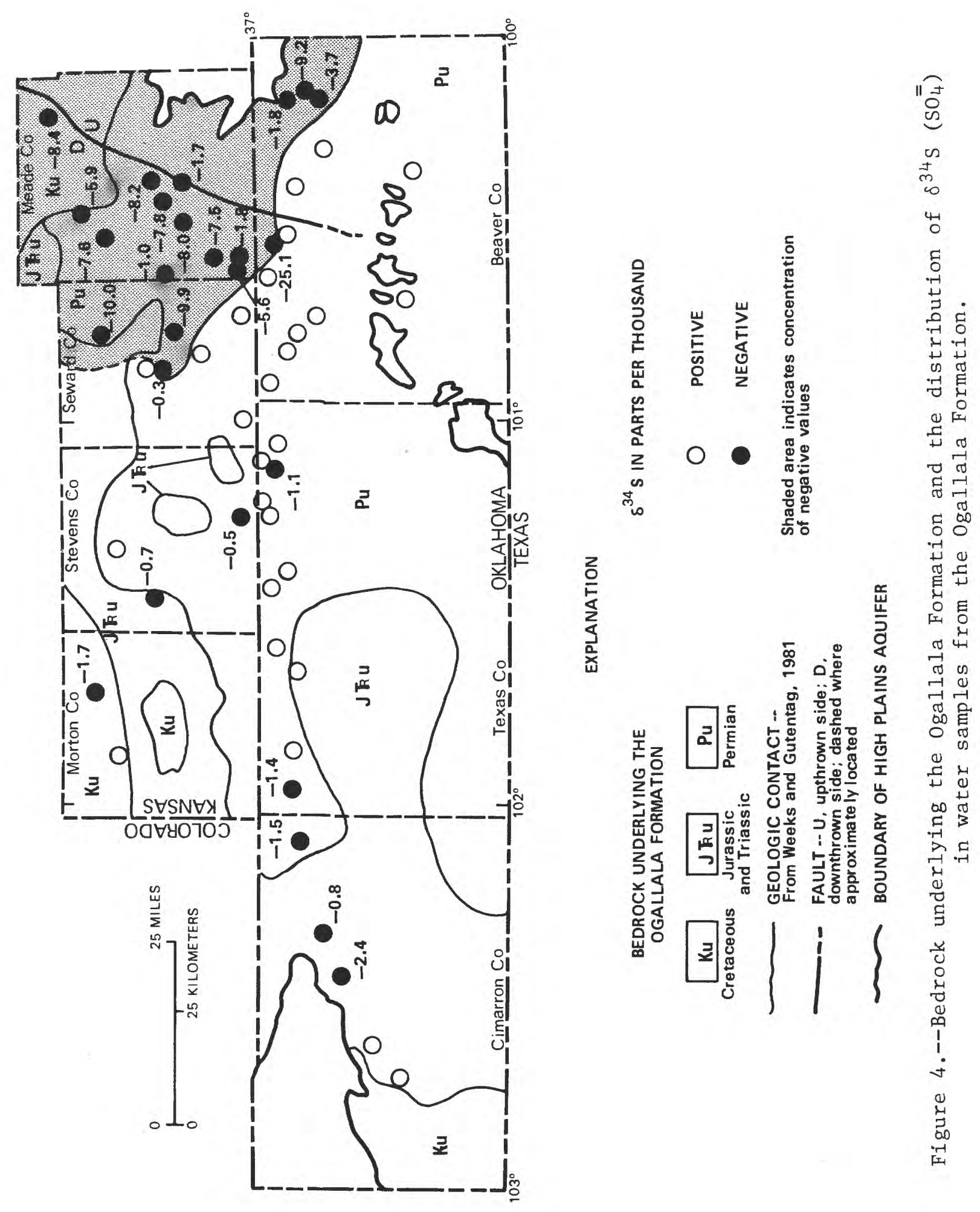


positive and ranged from +0.6 to $+8.50 / 00$, indicating that the negative values in the Ogallala Formation cannot be explained by simple mixing of water from the Ogallala and Permian rocks.

Isotopically light $\delta^{34} \mathrm{~S}\left(\mathrm{SO}_{4}^{\bar{N}}\right)$ values in water in the ogallala might be caused by migration of isotopically light $\mathrm{H}_{2} \mathrm{~S}$, produced by the bacterial reduction of sulfate in underlying formations (Reynolds and Goldhaber, 1978). $\mathrm{H}_{2} \mathrm{~S}$ may be migrating into the ogallala and oxidized into sulfate resulting in negative $\delta^{34} \mathrm{~S}\left(\mathrm{SO}_{4}^{\bar{*}}\right)$ values. Dissolved oxygen decreases eastward in the Ogallala Formation (tables 2 and 3 ) and could be caused by oxidation of $\mathrm{H}_{2} \mathrm{~S}$. The occurrence of ground water with low $\delta^{34} \mathrm{~S}\left(\mathrm{SO}_{4}^{\overline{4}}\right)$ values and high dissolved-solids concentrations in the eastern part of the study area could be explained by fracturing associated with faulting which would provide avenues for migration of $\mathrm{H}_{2} \mathrm{~S}$ and upward convection or diffusion of solutes. This mechanism also could explain why some samples have low $\delta^{34} \mathrm{~S}\left(\mathrm{SO}_{4}^{\overline{\bar{n}}}\right)$ values and low concentrations of dissolved solids and others have low $\delta^{34} \mathrm{~S}\left(\mathrm{SO}_{4}^{\overline{\bar{n}}}\right)$ values and high dissolvedsolids concentrations. The first case is influenced only by $\mathrm{H}_{2} \mathrm{~S}$ migration, which lowers the $\delta^{34} \mathrm{~S}\left(\mathrm{SO}_{4}\right)$ but does not appreciably affect the dissolvedsolids concentration. In the second case, appropriate amounts of $\mathrm{H}_{2} \mathrm{~S}$ and solutes are moving upward making the water in the Ogallala Formation isotopically light in sulfur and increasing its dissolved-solids concentration.

\section{CONCLUSIONS}

Results of this study indicate that the concentration of dissolved solids in Ogallala Formation water increases from west to east; this increase primarily is due to increases in the sodium, chloride, and sulfate content. An area of negative $\delta^{34} \mathrm{~S}\left(\mathrm{SO}_{4}^{\bar{E}}\right)$ values was found in the eastern part of the study area. The mechanism causing the variations in $\delta^{34} \mathrm{~S}\left(\mathrm{SO}_{4}^{\overline{4}}\right)$ values and solute concentrations has not been identified to the exclusion of other possibilities. However, it appears that the variations could be explained by migration of $\mathrm{H}_{2} \mathrm{~S}$ or upward convection or diffusion of solutes from the underlying Permian rocks. Additional data describing the occurrence of $\mathrm{H}_{2} \mathrm{~S}$, 
sulfur minerals, and sulfur isotopes, as well as hydraulic heads, in both the Ogallala Formation and Permian bedrock are needed to explain fully the changes in water chemistry. 
Table 2.--Chemical data from water samples collected from the High Plains aquifer in southwestern Kansas, 1979-80

[Analyses are in milligrams per liter except as indicated; ${ }^{\circ} \mathrm{C}=$ degrees Celsius; $\mu \mathrm{g} / \mathrm{L}=$ micrograms per 1iter; $\mathrm{NO}_{2}=$ nitrite; $\mathrm{NO}_{3}=$ nitrate; $\mathrm{CaCO}_{3}=$ calcium-carbonate; $\delta^{18} 0_{\text {SMOW }}=$ Del oxygen-18 referenced to Vienna standard mean ocean water; $\delta^{34} \mathrm{~S}_{\mathrm{CD}}=\mathrm{Del}$ sulfur-34 referenced to Canyon Diablo meteorite standard; $0 / 00=$ parts per thousand; irr. = irrigation; ind. = industrial; sto. = stock; dom.= domestic] 
Table 2.--Chemical data from water samples collected from the High Plains aquifer in southwestern Kansas, 1979-80--Continued

\begin{tabular}{|c|c|c|c|c|c|c|c|c|}
\hline $\begin{array}{c}\text { Map } \\
\text { number }\end{array}$ & $\begin{array}{l}\text { Latitude- } \\
\text { longitude }\end{array}$ & $\begin{array}{l}\text { We11 } \\
\text { depth } \\
\text { (feet) }\end{array}$ & $\begin{array}{c}\text { Use } \\
\text { of } \\
\text { water }\end{array}$ & $\begin{array}{c}\text { Temp- } \\
\text { era- } \\
\text { ture } \\
\left({ }^{\circ} \mathrm{C}\right)\end{array}$ & $\begin{array}{l}\text { Silica } \\
\left(\mathrm{SiO}_{2}\right)\end{array}$ & $\begin{array}{c}\text { Iron } \\
(\mathrm{Fe}) \\
(\mu \mathrm{g} / \mathrm{L})\end{array}$ & $\begin{array}{c}\text { Manga- } \\
\text { nese } \\
(\mathrm{Mn}) \\
(\mu \mathrm{g} / \mathrm{L})\end{array}$ & $\begin{array}{l}\text { Calcium } \\
\text { (Ca) }\end{array}$ \\
\hline 1 & 3715311015145 & 187 & Irr. & 16.2 & 29 & $<10$ & $<1$ & 39 \\
\hline 2 & 3719451014127 & 215 & $\operatorname{Irr}$. & 16.0 & 22 & $<10$ & $<3$ & 44 \\
\hline 3 & 3712461012907 & 360 & $\operatorname{Irr}$. & 16.3 & 26 & 20 & $<3$ & 100 \\
\hline 4 & 3716211011940 & 480 & $\operatorname{Irr}$. & 17.3 & 33 & $<10$ & $<1$ & 45 \\
\hline 5 & 3702181011033 & 400 & Irr. & 16.6 & 31 & $<10$ & $<3$ & 66 \\
\hline 6 & 3701281010040 & 353 & $\operatorname{Irr}$ & 16.1 & 30 & 10 & $<3$ & 110 \\
\hline 7 & 3712371005223 & 335 & Irr. & 17.3 & 25 & $<10$ & $<3$ & 63 \\
\hline 8 & 3711211005241 & 360 & $\operatorname{Irr}$ & 17.7 & 27 & 20 & $<1$ & 63 \\
\hline 9 & 3706421004906 & 360 & $\operatorname{Irr}$. & 17.5 & 31 & 10 & $<1$ & 61 \\
\hline 10 & 3716151004637 & 420 & $\operatorname{Irr}$ & 17.5 & 23 & $<10$ & $<1$ & 61 \\
\hline 11 & 3709571004538 & 232 & Ind. & 17.7 & 25 & $<10$ & $<1$ & 61 \\
\hline 12 & 3703001004536 & 285 & $\operatorname{Irr}$ & 17.4 & 31 & $<10$ & $<1$ & 52 \\
\hline 13 & 3702051004203 & 300 & $\operatorname{Irr}$ & 17.3 & 27 & $<10$ & $<3$ & 63 \\
\hline 14 & 3710371003716 & 425 & $\operatorname{Irr}$ & 17.9 & 29 & $<10$ & 10 & 79 \\
\hline 15 & 3701361003532 & 100 & Sto. & 18.0 & 25 & 40 & 2 & 53 \\
\hline 16 & 3709201003518 & 425 & $\operatorname{Irr}$ & 17.4 & 23 & $<10$ & $<3$ & 49 \\
\hline 17 & 3721171003547 & 200 & $\operatorname{Irr}$ & 16.3 & 21 & $<10$ & $<3$ & 48 \\
\hline 18 & 3704211003444 & 280 & $\operatorname{Irr}$. & 17.1 & 23 & $<10$ & $<3$ & 55 \\
\hline 19 & 3700591003420 & 260 & $\operatorname{Irr}$. & 18.0 & 23 & 10 & $<3$ & 63 \\
\hline 20 & 3717071003131 & 300 & $\operatorname{Irr}$ & 16.5 & 22 & $<10$ & $<3$ & 46 \\
\hline 21 & 3708131002924 & 445 & Irr. & 18.0 & 23 & $<10$ & $<3$ & 51 \\
\hline 22 & 3710221002710 & 300 & Dom. & 16.7 & 26 & $<10$ & $<1$ & 50 \\
\hline 23 & 3719441002500 & 250 & $\operatorname{Irr}$ & 16.6 & 25 & 10 & $<1$ & 56 \\
\hline 24 & 3711541002314 & 340 & Irr. & 17.3 & 24 & $<10$ & $<3$ & 51 \\
\hline 25 & 3708451002352 & 120 & Dom. & 16.6 & 25 & 20 & $<3$ & 30 \\
\hline 26 & 3724321001205 & 238 & $\operatorname{Irr}$ & 15.8 & 23 & $<10$ & $<3$ & 54 \\
\hline
\end{tabular}


Table 2.--Chemical data from water samples collected from the High Plains aquifer in southwestern Kansas, 1979-80--Continued

\begin{tabular}{|c|c|c|c|c|c|c|c|c|}
\hline $\begin{array}{c}\text { Map } \\
\text { number }\end{array}$ & $\begin{array}{l}\text { Magne- } \\
\text { sium } \\
(\mathrm{Mg})\end{array}$ & $\begin{array}{l}\text { Sodium } \\
(\mathrm{Na})\end{array}$ & $\begin{array}{l}\text { Potas- } \\
\text { sium } \\
(\mathrm{K})\end{array}$ & $\begin{array}{l}\text { Bicar- } \\
\text { bonate } \\
\left(\mathrm{HCO}_{3}\right)\end{array}$ & $\begin{array}{c}\text { Sulfate } \\
\left(\mathrm{SO}_{4}\right)\end{array}$ & $\begin{array}{l}\text { Chlor- } \\
\text { ride } \\
\text { (C1) }\end{array}$ & $\begin{array}{l}\text { Fluo- } \\
\text { ride } \\
\text { (F) }\end{array}$ & $\begin{array}{c}\text { Nitrogen } \\
\left(\mathrm{NO}_{2}+\mathrm{NO}_{3}\right. \\
\text { as } \mathrm{N})\end{array}$ \\
\hline 1 & 37 & 45 & 4.2 & 240 & 130 & 15 & --- & 2.6 \\
\hline 2 & 26 & 31 & 3.7 & 210 & 80 & 18 & 2.2 & 3.7 \\
\hline 3 & 45 & 68 & 5.5 & 240 & 230 & 100 & .7 & 11 \\
\hline 4 & 21 & 22 & 4.3 & 220 & 51 & 18 & .9 & 2.4 \\
\hline 5 & 19 & 18 & 3.7 & 190 & 80 & 27 & .6 & 3.8 \\
\hline 6 & 40 & 59 & 4.4 & 250 & 110 & 180 & .9 & 7.1 \\
\hline 7 & 24 & 32 & 4.2 & 220 & 110 & 19 & .9 & 3.5 \\
\hline 8 & 25 & 41 & 4.5 & 240 & 140 & 13 & .8 & 3.8 \\
\hline 9 & 18 & 26 & 3.6 & 230 & 59 & 19 & .4 & 4.7 \\
\hline 10 & 21 & 44 & 4.6 & 220 & 130 & 14 & .9 & 2.9 \\
\hline 11 & 21 & 49 & 4.6 & 230 & 130 & 12 & .9 & 2.8 \\
\hline 12 & 19 & 120 & 3.7 & 240 & 69 & 140 & .7 & 4.2 \\
\hline 13 & 16 & 95 & 4.2 & 240 & 51 & 140 & .8 & 4.3 \\
\hline 14 & 26 & 50 & 4.6 & 200 & 220 & 13 & 1.1 & 1.0 \\
\hline 15 & 18 & 49 & 4.3 & 210 & 91 & 44 & .9 & 1.9 \\
\hline 16 & 18 & 35 & 4.1 & 210 & 84 & 9.3 & 1.0 & 1.9 \\
\hline 17 & 12 & 22 & 3.7 & 190 & 39 & 9.4 & .9 & 2.1 \\
\hline 18 & 15 & 28 & 4.2 & 220 & 68 & 13 & 1.0 & 2.0 \\
\hline 19 & 19 & 240 & 4.6 & 210 & 94 & 350 & 1.0 & 1.7 \\
\hline 20 & 12 & 23 & 3.8 & 190 & 49 & 8.1 & .9 & 1.2 \\
\hline 21 & 14 & 21 & 3.6 & 200 & 47 & 8.4 & .9 & 2.0 \\
\hline 22 & 15 & 27 & 3.6 & 210 & 61 & 10 & .8 & 1.5 \\
\hline 23 & 12 & 18 & 3.8 & 230 & 33 & 17 & .6 & 2.8 \\
\hline 24 & 14 & 22 & 3.6 & 200 & 50 & 16 & 1.0 & 1.3 \\
\hline 25 & 9 & 250 & 3.1 & 240 & 77 & 270 & 1.2 & 1.2 \\
\hline 26 & 13 & 20 & 3.8 & 200 & 38 & 19 & .8 & 1.6 \\
\hline
\end{tabular}


Table 2.--Chemical data from water samples collected from the High Plains aquifer in southwestern Kansas, 1979-80--Continued

\begin{tabular}{|c|c|c|c|c|c|c|c|}
\hline \multirow{2}{*}{$\begin{array}{c}\text { Map } \\
\text { number }\end{array}$} & \multirow{2}{*}{$\begin{array}{l}\text { Iodide } \\
\text { (I) }\end{array}$} & \multirow{2}{*}{$\begin{array}{l}\text { Bromide } \\
(\mathrm{Br})\end{array}$} & \multirow{2}{*}{$\begin{array}{l}\text { Sele- } \\
\text { nium } \\
(\mathrm{Se}) \\
(\mu \mathrm{g} / \mathrm{L})\end{array}$} & \multirow{2}{*}{$\begin{array}{c}\text { Boron } \\
\text { (B) }\end{array}$} & \multirow{2}{*}{$\begin{array}{l}\text { Dis- } \\
\text { solved } \\
\text { solids } \\
\text { (sum) }\end{array}$} & \multicolumn{2}{|c|}{$\begin{array}{l}\text { Hardness } \\
\text { as } \mathrm{CaCO}_{3}\end{array}$} \\
\hline & & & & & & Total & $\begin{array}{l}\text { Non- } \\
\text { carbon- } \\
\text { ate }\end{array}$ \\
\hline 1 & 0.02 & 0.1 & 6 & 0.26 & 420 & 250 & 72 \\
\hline 2 & .01 & .2 & 6 & .20 & 334 & 220 & 57 \\
\hline 3 & .02 & 1.0 & 18 & .16 & 705 & 440 & 260 \\
\hline 4 & .01 & .1 & 3 & .10 & 304 & 200 & 30 \\
\hline 5 & .01 & .2 & 8 & .10 & 343 & 240 & 93 \\
\hline 6 & .02 & .7 & 22 & .10 & 665 & 440 & 250 \\
\hline 7 & .02 & .2 & 5 & .17 & 390 & 260 & 86 \\
\hline 8 & .04 & .2 & 5 & .23 & 414 & 260 & 63 \\
\hline 9 & .02 & .2 & 3 & .12 & 336 & 230 & 38 \\
\hline 10 & .01 & .2 & 9 & .17 & 410 & 240 & 70 \\
\hline 11 & .04 & .2 & 4 & .18 & 420 & 240 & 50 \\
\hline 12 & .03 & .3 & 4 & .12 & 558 & 210 & 11 \\
\hline 13 & .03 & .1 & 3 & .08 & 520 & 220 & 33 \\
\hline 14 & .03 & .2 & 2 & .19 & 522 & 300 & 140 \\
\hline 15 & .03 & .2 & 6 & .12 & 391 & 210 & 34 \\
\hline 16 & .01 & .1 & 6 & .14 & 329 & 200 & 36 \\
\hline 17 & .00 & .1 & 3 & .09 & 252 & 170 & 19 \\
\hline 18 & .01 & .1 & 6 & .12 & 318 & 200 & 29 \\
\hline 19 & .03 & .1 & 5 & .13 & 900 & 240 & 76 \\
\hline 20 & .00 & .1 & 5 & .28 & 260 & 160 & 14 \\
\hline 21 & .00 & .1 & 4 & .12 & 270 & 190 & 0 \\
\hline 22 & .03 & .1 & 4 & .09 & 298 & 190 & 14 \\
\hline 23 & .02 & .2 & 3 & .07 & 282 & 190 & 1 \\
\hline 24 & .01 & .1 & 7 & .08 & 282 & 190 & 35 \\
\hline 25 & .03 & .1 & 5 & .09 & 785 & 110 & 0 \\
\hline 26 & .01 & .1 & 4 & .05 & 272 & 190 & 28 \\
\hline
\end{tabular}


Table 2.--Chemical data from water samples collected from the High Plains aquifer in southwestem Kansas, 1979-80--Continued

\begin{tabular}{|c|c|c|c|c|c|c|}
\hline \multirow{2}{*}{$\begin{array}{c}\text { Map } \\
\text { number }\end{array}$} & \multirow{2}{*}{$\begin{array}{c}\text { Sodium } \\
\text { adsorp- } \\
\text { tion } \\
\text { ratio } \\
\text { (SAR) }\end{array}$} & \multirow{2}{*}{$\begin{array}{l}\text { Specific } \\
\text { conduct- } \\
\text { ance } \\
\text { (micro- } \\
\text { mhos at } \\
25^{\circ} \mathrm{C} \text { ) }\end{array}$} & \multirow{2}{*}{$\begin{array}{c}\mathrm{pH} \\
\text { (standard } \\
\text { units) }\end{array}$} & \multirow{2}{*}{$\begin{array}{l}\text { Dis- } \\
\text { solved } \\
\text { oxygen } \\
\text { (DO) }\end{array}$} & \multicolumn{2}{|c|}{ Isotopes } \\
\hline & & & & & $\begin{array}{c}\delta^{18} \mathrm{O}_{\text {SMOW }} \\
0 / 00\end{array}$ & $\begin{array}{c}\delta^{34} S_{C D} \\
0 / 00\end{array}$ \\
\hline 1 & 1.4 & 680 & 7.70 & 10.8 & -9.0 & 0.0 \\
\hline 2 & .9 & 580 & 7.72 & 10.6 & -9.5 & -1.7 \\
\hline 3 & 1.4 & 1,180 & 7.63 & 11.6 & -7.9 & -.7 \\
\hline 4 & .7 & 515 & 7.80 & 9.5 & -8.2 & .6 \\
\hline 5 & .5 & 590 & 7.75 & 7.8 & --- & -.5 \\
\hline 6 & 1.2 & 1,195 & 7.64 & 10.8 & -7.6 & 1.0 \\
\hline 7 & .9 & 670 & 7.68 & 7.9 & -8.4 & 1.0 \\
\hline 8 & 1.1 & 675 & 7.48 & 7.3 & -8.2 & -.3 \\
\hline 9 & .8 & 545 & 7.42 & 8.2 & -7.7 & 2.9 \\
\hline 10 & 1.3 & 690 & 7.70 & 7.6 & -8.5 & -10.0 \\
\hline 11 & 1.4 & 662 & 7.55 & 7.7 & -9.0 & -9.9 \\
\hline 12 & 3.6 & 990 & 7.40 & 7.4 & -7.8 & --- \\
\hline 13 & 2.8 & 935 & 7.73 & 8.6 & -7.6 & .9 \\
\hline 14 & 1.2 & 795 & 7.75 & 7.0 & -8.6 & -1.0 \\
\hline 15 & 1.5 & 625 & 7.42 & 6.0 & -8.1 & -5.6 \\
\hline 16 & 1.1 & 545 & 7.81 & 6.8 & -8.5 & --- \\
\hline 17 & .7 & 440 & 7.60 & 8.0 & -- & --- \\
\hline 18 & .9 & 535 & 7.72 & 8.2 & -- & -7.5 \\
\hline 19 & 6.8 & 1,650 & 7.68 & 7.2 & -8.6 & -1.8 \\
\hline 20 & .8 & 450 & 7.60 & 7.1 & -8.4 & -7.6 \\
\hline 21 & .7 & 470 & 7.70 & 7.4 & -8.2 & -8.0 \\
\hline 22 & .9 & 472 & 7.41 & 5.8 & -8.4 & -7.8 \\
\hline 23 & .6 & 480 & 7.30 & 7.6 & -7.5 & -5.9 \\
\hline 24 & .7 & 480 & 7.83 & --- & -8.3 & -8.2 \\
\hline 25 & 10 & 1,440 & 7.80 & 7.3 & -- & -1.7 \\
\hline 26 & .6 & 480 & 7.75 & 5.0 & -8.8 & -8.4 \\
\hline
\end{tabular}


Table 3.--Chemical data from water samples collected from the High Plains aquifer in the Oklahoma Panhandle, 1979-80

[Analyses are in milligrams per liter except as indicated; ${ }^{\circ} \mathrm{C}=$ degrees

Celsius; $\mu \mathrm{g} / \mathrm{L}=$ micrograms per liter; $\mathrm{NO}_{2}=$ nitrite; $\mathrm{NO}_{3}=$ nitrate;

$\mathrm{CaCO}_{3}=$ calcium-carbonate; $\delta^{18} \mathrm{O}_{\text {SMOW }}=\mathrm{Del}$ oxygen-18 referenced to

Vienna standard mean ocean water; $\delta{ }^{34} \mathrm{~S}_{\mathrm{CD}}=$ Del sulfur-34 referenced

to Canyon Diablo meteorite standard; $0 / 00=$ parts per thousand;

irr. = irrigation; ind. = industrial; sto. = stock; dom.= domestic $]$ 
Table 3.--Chemical data from water samples collected from the High Plains aquifer in the Oklahoma Panhandle, 1979-80--Continued

\begin{tabular}{|c|c|c|c|c|c|c|c|c|}
\hline $\begin{array}{c}\text { Map } \\
\text { number }\end{array}$ & $\begin{array}{l}\text { Latitude- } \\
\text { longitude }\end{array}$ & $\begin{array}{l}\text { Wel1 } \\
\text { depth } \\
\text { (feet) }\end{array}$ & $\begin{array}{c}\text { Use } \\
\text { of } \\
\text { water }\end{array}$ & $\begin{array}{l}\text { Temp- } \\
\text { era- } \\
\text { ture } \\
\left({ }^{\circ} \mathrm{C}\right)\end{array}$ & $\begin{array}{l}\text { Silica } \\
\left(\mathrm{SiO}_{2}\right)\end{array}$ & $\begin{array}{c}\text { Iron } \\
(\mathrm{Fe}) \\
(\mu \mathrm{g} / \mathrm{L})\end{array}$ & $\begin{array}{c}\text { Manga- } \\
\text { nese } \\
(\mathrm{Mn}) \\
(\mu \mathrm{g} / \mathrm{L})\end{array}$ & $\begin{array}{l}\text { Calcium } \\
\quad \text { (Ca) }\end{array}$ \\
\hline 27 & 3645431023621 & 230 & Irr. & 17.1 & 33 & $<10$ & $<1$ & 49 \\
\hline 28 & 3645461023057 & 275 & Irr. & 18.3 & 27 & $<10$ & $<1$ & 34 \\
\hline 29 & 3648521021908 & 220 & Irr. & 16.8 & 34 & $<10$ & $<1$ & 35 \\
\hline 30 & 3650321021451 & 270 & Irr. & 17.0 & 38 & $<10$ & $<1$ & 34 \\
\hline 31 & 3653321020835 & 230 & Dom. & 16.8 & 30 & 20 & 3 & 40 \\
\hline 32 & 3654141020348 & 237 & Dom. & 17.7 & 30 & $<10$ & $<1$ & 25 \\
\hline 33 & 3655171015649 & 350 & Irr. & 17.6 & 30 & $<10$ & $<1$ & 30 \\
\hline 34 & 3657251015616 & 200 & Sto. & 17.8 & 24 & $<10$ & 2 & 30 \\
\hline 35 & 3655161015119 & 360 & Dom. & 17.1 & 27 & $<10$ & $<1$ & 31 \\
\hline 36 & 3657571014805 & 300 & Dom. & 16.9 & 29 & 10 & $<1$ & 58 \\
\hline 37 & 3657441014420 & 285 & Dom. & 17.1 & 29 & $<10$ & $<1$ & 57 \\
\hline 38 & 3655031014155 & 345 & Irr. & 17.3 & 25 & $<10$ & $<1$ & 38 \\
\hline 39 & 3657541013755 & 250 & Dom. & 17.1 & 27 & $<10$ & $<1$ & 79 \\
\hline 40 & 3658431013140 & 400 & Dom. & 17.8 & 33 & 10 & $<1$ & 70 \\
\hline 41 & 3657541012401 & 300 & Dom. & 17.0 & 34 & 40 & $<1$ & 85 \\
\hline 42 & 3655411012136 & 427 & Irr. & 18.0 & 34 & $<10$ & $<1$ & 82 \\
\hline 43 & 3659141011503 & 140 & Dom. & 16.9 & 33 & 20 & $<1$ & 91 \\
\hline 44 & 3658471011108 & 165 & Dom. & 16.6 & 23 & 20 & 2 & 72 \\
\hline 45 & 3659111011046 & 428 & $\operatorname{Irr}$ & 17.1 & 34 & $<10$ & $<1$ & 63 \\
\hline 46 & 3659101010631 & 635 & Irr. & 17.8 & 36 & 10 & $<1$ & 60 \\
\hline 47 & 3659361010626 & 354 & Irr. & 17.4 & 34 & 10 & $<1$ & 60 \\
\hline 48 & 3658441010343 & 522 & Irr. & 17.6 & 33 & 30 & 2 & 55 \\
\hline 49 & 3657521005908 & 125 & Dom. & 16.2 & 28 & $<10$ & $<1$ & 100 \\
\hline 50 & 3658441005353 & 100 & Dom. & 16.9 & 38 & 30 & 5 & 36 \\
\hline 51 & 3658571005017 & 280 & Dom. & 17.5 & 33 & 20 & $<1$ & 49 \\
\hline 52 & 3656251004928 & 465 & $\operatorname{Irr}$ & 17.7 & 38 & $<10$ & $<1$ & 55 \\
\hline 53 & 3655341004703 & 280 & Dom. & 17.9 & 38 & 10 & $<1$ & 52 \\
\hline 54 & 3653221004227 & 400 & Irr. & 18.4 & 31 & $<10$ & $<3$ & 64 \\
\hline 55 & 3656391004020 & 100 & Dom. & 16.2 & 33 & 30 & $<1$ & 76 \\
\hline 56 & 3642381003904 & 500 & Irr. & 17.3 & 37 & $<10$ & $<3$ & 45 \\
\hline
\end{tabular}


Table 3.--Chemical data from water samples collected from the High Plains aquifer in the Oklahoma Panhandle, 1979-80--Continued

\begin{tabular}{|c|c|c|c|c|c|c|c|c|}
\hline $\begin{array}{c}\text { Map } \\
\text { number }\end{array}$ & $\begin{array}{l}\text { Latitude- } \\
\text { longitude }\end{array}$ & $\begin{array}{l}\text { Well } \\
\text { depth } \\
\text { (feet) }\end{array}$ & $\begin{array}{c}\text { Use } \\
\text { of } \\
\text { water }\end{array}$ & $\begin{array}{c}\text { Temp- } \\
\text { era- } \\
\text { ture } \\
\left({ }^{\circ} \mathrm{C}\right)\end{array}$ & $\begin{array}{l}\text { Silica } \\
\left(\mathrm{SiO}_{2}\right)\end{array}$ & $\begin{array}{c}\text { Iron } \\
(\mathrm{Fe}) \\
(\mu \mathrm{g} / \mathrm{L})\end{array}$ & $\begin{array}{c}\text { Manga- } \\
\text { nese } \\
(\mathrm{Mn}) \\
(\mu \mathrm{g} / \mathrm{L})\end{array}$ & $\begin{array}{l}\text { Calcium } \\
\text { (Ca) }\end{array}$ \\
\hline 57 & 3658231003537 & 480 & Dom. & 18.5 & 33 & 50 & 10 & 90 \\
\hline 58 & 3657031003338 & 125 & Sto. & 17.3 & 29 & 50 & 3 & 83 \\
\hline 59 & 3658001003000 & 200 & Irr. & 17.3 & 30 & 20 & 5 & 53 \\
\hline 60 & 3656101002917 & 124 & Dom. & 18.9 & 34 & 20 & 2 & 69 \\
\hline 61 & 3655231002200 & 80 & Sto. & 17.8 & 30 & 110 & 20 & 110 \\
\hline 62 & 3641191001604 & 180 & Irr. & 16.9 & 35 & $<10$ & $<1$ & 46 \\
\hline 63 & 3652281001146 & 200 & Dom. & 18.1 & - & $<10$ & $<1$ & 96 \\
\hline 64 & 3654261001014 & 80 & Sto. & 17.8 & 31 & 80 & 3 & 120 \\
\hline 65 & 3656061000434 & 80 & Irr. & 17.5 & 31 & $<10$ & $<3$ & 110 \\
\hline 66 & 3652371000233 & 200 & Irr. & 16.8 & 34 & 30 & 6 & 75 \\
\hline 67 & 3653271000223 & 84 & Sto. & 17.3 & 51 & 400 & 130 & 110 \\
\hline
\end{tabular}


Table 3.--Chemical data from water samples collected from the High Plains aquifer in the Oklahoma Panhandle, 1979-80--Continued

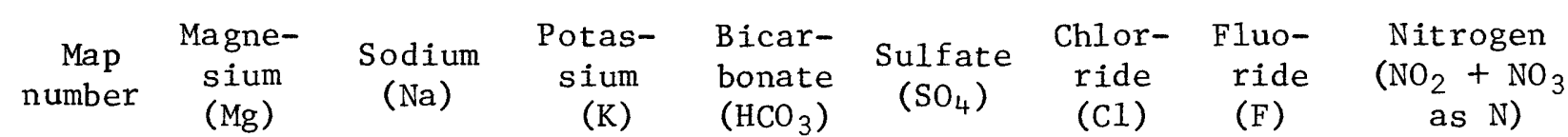

\begin{tabular}{|c|c|c|c|c|c|c|c|c|}
\hline 27 & 29 & 20 & 4.4 & 230 & 49 & 33 & 1.4 & 3.7 \\
\hline 28 & 26 & 24 & 5.1 & 220 & 36 & 12 & 1.4 & 3.1 \\
\hline 29 & 35 & 21 & 5.6 & 220 & 63 & 37 & 2.2 & 2.3 \\
\hline 30 & 34 & 19 & 5.1 & 210 & 53 & 15 & 2.3 & 1.2 \\
\hline 31 & 27 & 22 & 5.9 & 210 & 33 & 35 & 2.4 & 4.9 \\
\hline 32 & 26 & 20 & 6.6 & 240 & 20 & 4.1 & 2.9 & 1.7 \\
\hline 33 & 29 & 26 & 6.3 & 230 & 42 & 19 & 2.3 & 2.0 \\
\hline 34 & 29 & 31 & 6.1 & 250 & 65 & 10 & 1.9 & 1.9 \\
\hline 35 & 27 & 32 & 6.3 & 240 & 54 & 14 & 2.1 & 2.0 \\
\hline 36 & 29 & 36 & 5.1 & 300 & 61 & 23 & 1.0 & 5.5 \\
\hline 37 & 14 & 17 & 5.3 & 240 & 30 & 7.2 & .6 & 4.8 \\
\hline 38 & 29 & 33 & 5.8 & 240 & 67 & 10 & 2.0 & 2.3 \\
\hline 39 & 47 & 40 & 8.4 & 190 & 79 & 140 & 1.2 & 6.6 \\
\hline 40 & 16 & 20 & 3.4 & 180 & 89 & 35 & .4 & 4.2 \\
\hline 41 & 20 & 28 & 3.5 & 190 & 170 & 17 & .4 & 2.7 \\
\hline 42 & 23 & 23 & 3.8 & 200 & 150 & 12 & .5 & 2.8 \\
\hline 43 & 21 & 21 & 3.7 & 200 & 83 & 69 & .5 & 7.8 \\
\hline 44 & 21 & 23 & 4.0 & 220 & 54 & 44 & .6 & 9.3 \\
\hline 45 & 21 & 26 & 4.0 & 220 & 95 & 23 & .5 & 3.4 \\
\hline 46 & 23 & 29 & 4.0 & 210 & 81 & 13 & .6 & 3.5 \\
\hline 47 & 26 & 28 & 4.4 & 230 & 86 & 33 & .6 & 4.8 \\
\hline 48 & 21 & 27 & 4.1 & 220 & 70 & 21 & .5 & 4.2 \\
\hline 49 & 64 & 43 & .9 & 350 & 110 & 110 & 1.1 & 14 \\
\hline 50 & 28 & 27 & 3.9 & 250 & 47 & 20 & 1.7 & 3.5 \\
\hline 51 & 22 & 37 & 3.9 & 250 & 66 & 20 & 1.3 & 2.8 \\
\hline 52 & 27 & 76 & 4.4 & 250 & 70 & 98 & 1.5 & 3.0 \\
\hline 53 & 24 & 37 & 3.7 & 240 & 61 & 29 & 1.1 & 3.0 \\
\hline 54 & 31 & 130 & 5.8 & 250 & 74 & 230 & .9 & 2.9 \\
\hline 55 & 18 & 36 & 5.0 & 260 & 25 & 56 & 2.5 & 12 \\
\hline 56 & 22 & 28 & 5.0 & 240 & 28 & 24 & 1.5 & 2.5 \\
\hline
\end{tabular}


Table 3.--Chemical data from water samples collected from the High Plains aquifer in the OkZahoma Panhandle, 1979-80--Continued

$\begin{array}{ccccccccc}\text { Map } & \begin{array}{c}\text { Magne- } \\ \text { sium }\end{array} & \text { Sodium } & \begin{array}{c}\text { Potas- } \\ \text { sium }\end{array} & \begin{array}{c}\text { Bicar- } \\ \text { bonate }\end{array} & \begin{array}{c}\text { Sulfate } \\ \left(\mathrm{SO}_{4}\right)\end{array} & \begin{array}{c}\text { Chlor- } \\ \text { ride }\end{array} & \begin{array}{c}\text { Fluo- } \\ \text { ride }\end{array} & \begin{array}{c}\text { Nitrogen } \\ \left(\mathrm{NO}_{2}+\mathrm{NO}_{3}\right.\end{array} \\ \text { number } & (\mathrm{Mg}) & (\mathrm{Na}) & (\mathrm{K}) & \left(\mathrm{HCO}_{3}\right) & & (\mathrm{F}) & \text { as } \mathrm{N})\end{array}$

$\begin{array}{rrrrrrrrr}57 & 41 & 210 & 5.8 & 240 & 110 & 370 & 0.8 & 2.1 \\ 58 & 79 & 99 & 9.9 & 420 & 310 & 44 & 2.1 & 9.2 \\ 59 & 25 & 140 & 4.0 & 250 & 200 & 110 & .7 & 1.0 \\ 60 & 17 & 40 & 4.1 & 250 & 50 & 53 & .6 & 4.8 \\ 61 & 26 & 27 & 4.3 & 220 & 24 & 170 & .7 & 2.1 \\ & & & & & & & & \\ 62 & 14 & 100 & 3.6 & 250 & 49 & 100 & 1.2 & 3.5 \\ 63 & 22 & 25 & 4.1 & 220 & 59 & 74 & .6 & 12 \\ 64 & 11 & 4 & 2.1 & 400 & 14 & 2.0 & .3 & 5.0 \\ 65 & 29 & 72 & 5.0 & 320 & 200 & 57 & 1.0 & 1.8 \\ 66 & 25 & 37 & 3.3 & 310 & 63 & 38 & .7 & 3.5 \\ 67 & 32 & 120 & 5.9 & 340 & 130 & 190 & 1.4 & .3\end{array}$


Table 3.--Chemical data from water samples collected from the High Plains aquifer in the Oklahoma Panhandle, 1979-80--Continued

\begin{tabular}{|c|c|c|c|c|c|c|c|}
\hline \multirow{2}{*}{$\begin{array}{c}\text { Map } \\
\text { number }\end{array}$} & \multirow{2}{*}{$\begin{array}{l}\text { Iodide } \\
\text { (I) }\end{array}$} & \multirow{2}{*}{$\begin{array}{l}\text { Bromide } \\
\text { (Br) }\end{array}$} & \multirow{2}{*}{$\begin{array}{l}\text { Sele- } \\
\text { nium } \\
(\mathrm{Se}) \\
(\mu \mathrm{g} / \mathrm{L})\end{array}$} & \multirow{2}{*}{$\begin{array}{l}\text { Boron } \\
\text { (B) }\end{array}$} & \multirow{2}{*}{$\begin{array}{l}\text { Dis- } \\
\text { solved } \\
\text { solids } \\
\text { (sum) }\end{array}$} & \multicolumn{2}{|c|}{$\begin{array}{l}\text { Hardness } \\
\text { as } \mathrm{CaCO}_{3}\end{array}$} \\
\hline & & & & & & Total & $\begin{array}{l}\text { Non- } \\
\text { carbon- } \\
\text { ate }\end{array}$ \\
\hline 27 & 0.05 & 0.3 & 5 & 0.17 & 336 & 240 & 53 \\
\hline 28 & .03 & .2 & 3 & .13 & 277 & 190 & 11 \\
\hline 29 & .07 & .6 & 6 & .12 & 344 & 230 & 51 \\
\hline 30 & .05 & .2 & 6 & .13 & 305 & 220 & 53 \\
\hline 31 & .08 & .4 & 3 & .16 & 304 & 210 & 39 \\
\hline 32 & .02 & .1 & 1 & .17 & 255 & 170 & 0 \\
\hline 33 & .01 & .2 & 3 & .20 & 300 & 190 & 6 \\
\hline 34 & .06 & .1 & 2 & .19 & 322 & 190 & 0 \\
\hline 35 & .08 & .2 & 2 & .13 & 314 & 190 & 0 \\
\hline 36 & .05 & .3 & 1 & .32 & 396 & 260 & 18 \\
\hline 37 & .01 & .1 & 1 & .23 & 283 & 200 & 3 \\
\hline 38 & .05 & .2 & 3 & .25 & 331 & 210 & 17 \\
\hline 39 & .07 & 1.1 & 10 & .19 & 523 & 390 & 240 \\
\hline 40 & .03 & .5 & 7 & .10 & 360 & 240 & 93 \\
\hline 41 & .02 & .2 & 4 & .11 & 454 & 290 & 140 \\
\hline 42 & .03 & .2 & 4 & .10 & 430 & 300 & 140 \\
\hline 43 & .02 & .6 & 14 & .04 & 429 & 310 & 150 \\
\hline 44 & .01 & .4 & 6 & .16 & 360 & 270 & 86 \\
\hline 45 & .02 & .2 & 6 & .12 & 378 & 240 & 63 \\
\hline 46 & .03 & .2 & 5 & .09 & 354 & 240 & 72 \\
\hline 47 & .03 & .4 & 11 & .11 & 390 & 260 & 68 \\
\hline 48 & .03 & .2 & 7 & .12 & 344 & 220 & 43 \\
\hline 49 & .05 & 1.0 & 17 & .10 & 644 & 510 & 230 \\
\hline 50 & .03 & .2 & 5 & .09 & 328 & 210 & 0 \\
\hline 51 & .05 & .2 & 4 & .12 & 358 & 210 & 8 \\
\hline 52 & .04 & .3 & 5 & .09 & 496 & 250 & 43 \\
\hline 53 & .03 & .2 & 5 & .12 & 367 & 230 & 32 \\
\hline 54 & .04 & .1 & 6 & .14 & 693 & 290 & 87 \\
\hline 55 & .04 & .3 & 3 & .11 & 392 & 260 & 51 \\
\hline 56 & .01 & .1 & 1 & .08 & 311 & 200 & 13 \\
\hline
\end{tabular}


Table 3.--Chemical data from water samples collected from the High Plains aquifer in the Oklahoma Panhandle, 1979-80--Continued

\begin{tabular}{|c|c|c|c|c|c|c|c|}
\hline \multirow{2}{*}{$\begin{array}{c}\text { Map } \\
\text { number }\end{array}$} & \multirow{2}{*}{$\begin{array}{l}\text { Iodide } \\
\text { (I) }\end{array}$} & \multirow{2}{*}{$\begin{array}{l}\text { Bromide } \\
\quad(\mathrm{Br})\end{array}$} & \multirow{2}{*}{$\begin{array}{l}\text { Sele- } \\
\text { nium } \\
(\mathrm{Se}) \\
(\mu \mathrm{g} / \mathrm{L})\end{array}$} & \multirow{2}{*}{$\begin{array}{l}\text { Boron } \\
\text { (B) }\end{array}$} & \multirow{2}{*}{$\begin{array}{l}\text { Dis- } \\
\text { solved } \\
\text { solids } \\
\text { (sum) }\end{array}$} & \multicolumn{2}{|c|}{$\begin{array}{l}\text { Hardness } \\
\text { as } \mathrm{CaCO}_{3}\end{array}$} \\
\hline & & & & & & Total & $\begin{array}{l}\text { Non- } \\
\text { carbon- } \\
\text { ate }\end{array}$ \\
\hline 57 & 0.05 & 0.6 & 7 & 0.09 & 986 & 390 & 200 \\
\hline 58 & .32 & .2 & 39 & .32 & 872 & 530 & 190 \\
\hline 59 & .03 & .2 & 2 & .12 & 693 & 250 & 45 \\
\hline 60 & .03 & .3 & 4 & .07 & 396 & 240 & 37 \\
\hline 61 & .01 & .3 & 0 & .06 & 503 & 380 & 200 \\
\hline 62 & .02 & .1 & 1 & .08 & 476 & 170 & 0 \\
\hline 63 & .01 & .3 & 8 & .06 & 401 & 330 & 170 \\
\hline 64 & .04 & .1 & 1 & .06 & 387 & 350 & 17 \\
\hline 65 & .01 & .1 & 12 & .14 & 665 & 390 & 150 \\
\hline 66 & .03 & .2 & 4 & .14 & 432 & 290 & 36 \\
\hline 67 & .09 & .6 & 16 & .14 & 809 & 410 & 130 \\
\hline
\end{tabular}


Table 3.--Chemical data from water samples collected from the High Plains aquifer in the Oklahoma Panhandle, 1979-80--Continued

\begin{tabular}{|c|c|c|c|c|c|c|}
\hline \multirow[b]{2}{*}{$\begin{array}{c}\text { Map } \\
\text { number }\end{array}$} & \multirow{2}{*}{$\begin{array}{l}\text { Sodium } \\
\text { adsorp- } \\
\text { tion } \\
\text { ratio } \\
\text { (SAR) }\end{array}$} & \multirow{2}{*}{$\begin{array}{l}\text { Specific } \\
\text { conduct- } \\
\text { ance } \\
\text { (micro- } \\
\text { mhos at } \\
25^{\circ} \mathrm{C} \text { ) }\end{array}$} & \multirow{2}{*}{$\begin{array}{c}\mathrm{pH} \\
\text { (standard } \\
\text { units) }\end{array}$} & \multirow{2}{*}{$\begin{array}{l}\text { Dis- } \\
\text { solved } \\
\text { oxygen } \\
\text { (D0) }\end{array}$} & \multicolumn{2}{|c|}{ Isotopes } \\
\hline & & & & & $\begin{array}{c}\delta^{18} \mathrm{O}_{\text {SMOW }} \\
0 / 00\end{array}$ & $\begin{array}{c}\delta^{34} S_{C D} \\
0 / 00\end{array}$ \\
\hline 27 & 0.6 & 555 & 7.40 & 8.9 & -7.7 & 2.4 \\
\hline 28 & .8 & 465 & 7.55 & --- & -7.7 & 1.3 \\
\hline 29 & .6 & 570 & 7.45 & 8.2 & -7.5 & -2.4 \\
\hline 30 & .6 & 482 & 7.55 & 7.9 & -7.3 & -.8 \\
\hline 31 & .7 & 525 & 7.43 & 13.4 & -7.7 & --- \\
\hline 32 & .7 & 408 & 7.54 & 8.4 & -8.1 & -1.5 \\
\hline 33 & .8 & 472 & 7.49 & 9.5 & -7.7 & -1.4 \\
\hline 34 & 1.0 & 530 & 7.51 & 8.1 & -- & --- \\
\hline 35 & 1.0 & 502 & 7.51 & 9.1 & -7.8 & .2 \\
\hline 36 & 1.0 & 680 & 7.25 & 8.2 & -6.8 & --- \\
\hline 37 & .5 & 470 & 7.20 & 10.6 & --- & --- \\
\hline 38 & 1.0 & 530 & 7.40 & 7.9 & -8.0 & 1.6 \\
\hline 39 & .9 & 905 & 7.30 & 8.9 & -8.0 & .4 \\
\hline 40 & .6 & 585 & 7.38 & 9.1 & -- & --- \\
\hline 41 & .7 & 662 & 7.20 & 7.8 & -7.8 & 3.1 \\
\hline 42 & .6 & 620 & 7.35 & 7.6 & -7.8 & 1.0 \\
\hline 43 & .5 & 770 & 7.20 & 9.9 & -7.3 & - \\
\hline 44 & .6 & 620 & 7.29 & 10.9 & -7.0 & 2.8 \\
\hline 45 & .7 & 588 & 7.40 & 7.9 & -7.9 & 3.6 \\
\hline 46 & .8 & 540 & 7.42 & 8.3 & -8.7 & -1.1 \\
\hline 47 & .8 & 632 & 7.35 & 10.5 & -8.0 & 2.6 \\
\hline 48 & .8 & 552 & 7.40 & 8.9 & -8.1 & 1.2 \\
\hline 49 & .8 & 1,140 & 7.00 & 8.5 & -7.0 & --- \\
\hline 50 & .8 & 515 & 7.40 & 6.1 & -8.1 & .5 \\
\hline 51 & 1.1 & 582 & 7.30 & 7.4 & -8.3 & --- \\
\hline 52 & 2.1 & 840 & 7.38 & 7.7 & -8.1 & 2.4 \\
\hline 53 & 1.1 & 590 & 7.35 & 6.4 & -8.1 & .0 \\
\hline 54 & 3.3 & 1,280 & 7.78 & 6.2 & -7.7 & 1.5 \\
\hline 55 & 1.0 & 750 & 7.10 & 9.4 & -7.3 & --- \\
\hline 56 & .9 & 520 & 7.55 & 7.8 & --- & 6.2 \\
\hline
\end{tabular}


Table 3.--Chemical data from water samples collected from the High Plains aquifer in the Oklahoma Panhandle, 1979-80--Continued

\begin{tabular}{|c|c|c|c|c|c|c|}
\hline \multirow{2}{*}{$\begin{array}{c}\text { Map } \\
\text { number }\end{array}$} & \multirow{2}{*}{$\begin{array}{c}\text { Sodium } \\
\text { adsorp- } \\
\text { tion } \\
\text { ratio } \\
\text { (SAR) }\end{array}$} & \multirow{2}{*}{$\begin{array}{c}\text { Specific } \\
\text { conduct- } \\
\text { ance } \\
\text { (micro- } \\
\text { mhos at } \\
25^{\circ} \mathrm{C} \text { ) }\end{array}$} & \multirow{2}{*}{$\begin{array}{c}\mathrm{pH} \\
\text { (standard } \\
\text { units) }\end{array}$} & \multirow{2}{*}{$\begin{array}{l}\text { Dis- } \\
\text { solved } \\
\text { oxygen } \\
\text { (DO) }\end{array}$} & \multicolumn{2}{|c|}{ Isotopes } \\
\hline & & & & & $\begin{array}{c}{ }^{{ }^{18} \mathrm{O}_{\text {SMOW }}} \\
0 / 00\end{array}$ & $\begin{array}{c}{ }^{\delta 34} S_{C D} \\
0 / 00\end{array}$ \\
\hline 57 & 4.6 & 1,780 & 7.28 & 4.5 & -7.9 & 1.6 \\
\hline 58 & 1.9 & 1,310 & 7.42 & 6.2 & -6.1 & -- \\
\hline 59 & 3.9 & 1,155 & 7.50 & 7.7 & -7.2 & -25.1 \\
\hline 60 & 1.1 & 685 & 7.20 & 9.6 & -7.4 & 2.6 \\
\hline 61 & .6 & 945 & 7.43 & 8.6 & -7.1 & 3.6 \\
\hline 62 & 3.6 & 855 & 7.71 & 7.8 & -7.8 & 6.9 \\
\hline 63 & .6 & 785 & 7.50 & 7.8 & -- & 1.5 \\
\hline 64 & .1 & 608 & 6.85 & 4.2 & -2.6 & --- \\
\hline 65 & 1.6 & 1,050 & 7.45 & 5.9 & -- & -1.8 \\
\hline 66 & .9 & 692 & 7.35 & 6.4 & -7.1 & -3.7 \\
\hline 67 & 2.6 & 1,305 & 7.35 & 3.9 & -6.7 & -9.2 \\
\hline
\end{tabular}


Gutentag, E. D., and Weeks, J. B., 1980, Water table in the High P1ains aquifer in 1978 in parts of Colorado, Kansas, Nebraska, New Mexico, Oklahoma, South Dakota, Texas, and Wyoming: U.S. Geological Survey Hydrologic Investigations Atlas HA-642.

Hart, D. L., Hoffman, G. L., and Goematt, R. L., 1976, Geohydrology of the Oklahoma Panhandle; Beaver, Texas, and Cimarron Counties: U.S. Geological Survey Water-Resources Investigations 25-75, 62 p.

Hathaway, L. R., Carr, B. L., Flanagan, M. A., Galle, O. K., Waugh, T. C., Dickey, H. P., and Magnuson, L. M., 1978, Chemical quality of irrigation waters in southwestern Kansas: Kansas Geological Survey Chemical Quality Series 6, $35 \mathrm{p}$.

Reynolds, R. L., and Goldhaber, M. B., 1978, Origin of a south Texas rol1type uranium deposit: alteration of iron-titanium oxide minerals: Economic Geology, v. 73, p. 1677-1689.

Rightmire, C. T., Pearson, F. J., Back. W., Rye, R. O., and Hanshaw, B. B., 1974, Distribution of sulphur isotopes of sulphate in ground waters from the principal artesian aquifer of Florida and the Edwards aquifer of Texas: International Atomic Energy Agency Proceedings, Symposium on Isotope techniques in ground-water hydrology, p. 191-207.

Thode, H. S., Monster, J., and Dunford, H. B., 1961, Sulphur isotope geochemistry: Geochimica et Cosmochimica Acta 25, p. 159-174.

Weeks, J. B., and Gutentag, E. D., 1981, Bedrock geology, a1titude of base, and 1980 saturated thickness of the High Plains aquifer in parts of Colorado, Kansas, Nebraska, New Mexico, Oklahoma, South Dakota, Texas, and Wyoming: U.S. Geological Survey Hydrologic Investigations At 1 as $\mathrm{HA}-648$. 